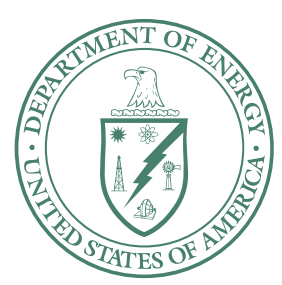

U.S. Department of Energy

Idaho Operations Office

\title{
ICDF Complex Operations Waste Management Plan
}

December 2006 
DOE/ID-10886

Revision 1

Project No. 23350

\section{ICDF Complex Operations Waste Management Plan}

December 2006

Prepared for the

U.S. Department of Energy

DOE Idaho Operations Office 



\begin{abstract}
This Waste Management Plan functions as a management and planning tool for managing waste streams generated as a result of operations at the Idaho CERCLA Disposal Facility (ICDF) Complex.

The waste management activities described in this plan support the selected remedy presented in the Waste Area Group 3, Operable Unit 3-13 Final Record of Decision for the operation of the Idaho CERCLA Disposal Facility Complex. This plan identifies the types of waste that are anticipated during operations at the Idaho CERCLA Disposal Facility Complex. In addition, this plan presents management strategies and disposition for these anticipated waste streams.
\end{abstract}




\section{CONTENTS}

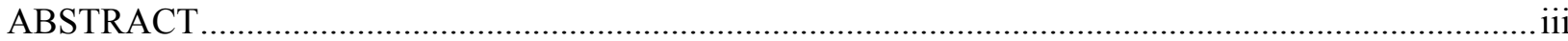

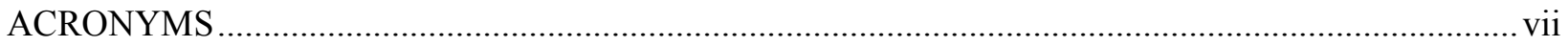

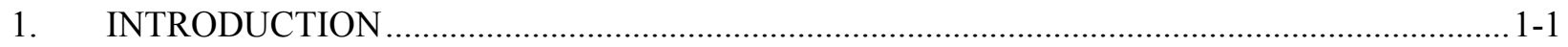

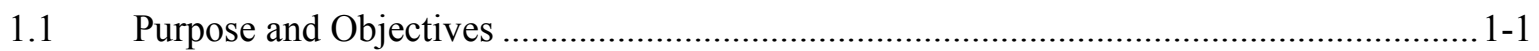

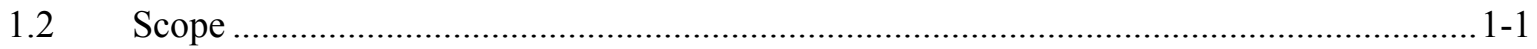

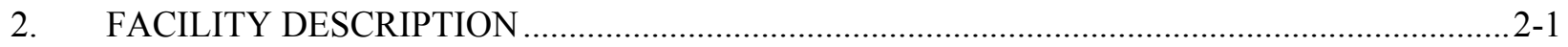

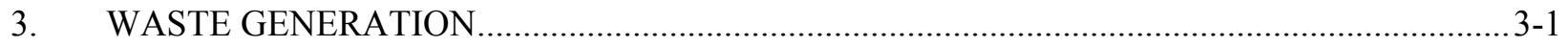

3.1 Waste Management Assumptions ….........................................................................

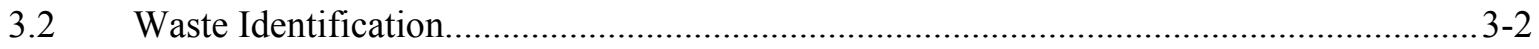

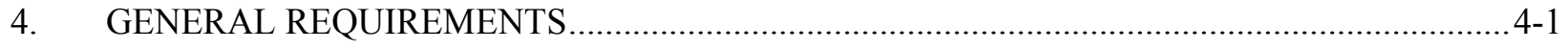

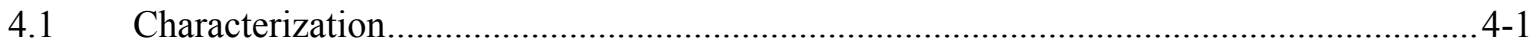

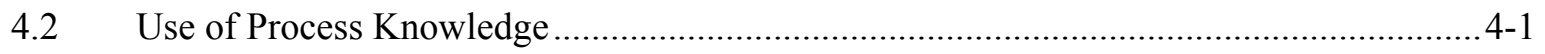

4.3 Waste Minimization and Pollution Prevention............................................................. 4-1

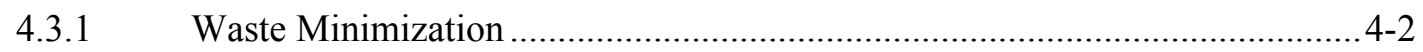

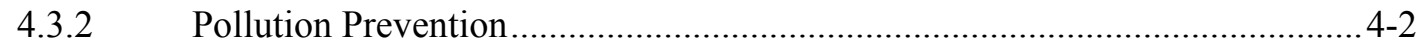

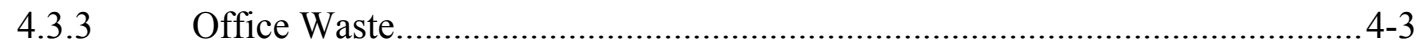

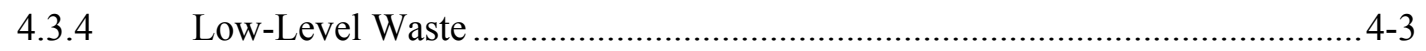

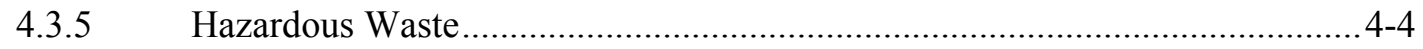

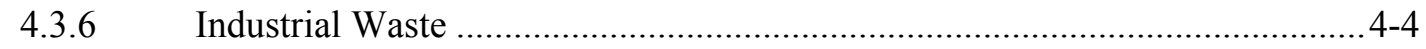

5. MANAGEMENT AND DISPOSITION OF WASTE ..........................................................

5.1 Management in Storage/Staging Areas ................................................................ $5-1$

5.1.1 Management in Storage Areas .................................................................. 5-1

5.1.2 Management in Staging Areas .............................................................. $5-1$

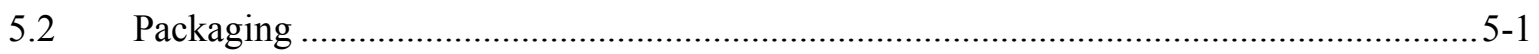

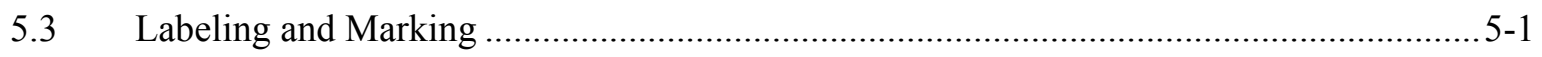

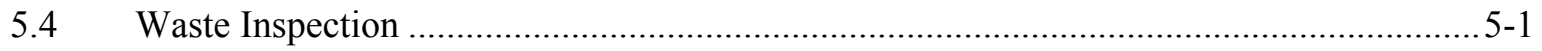

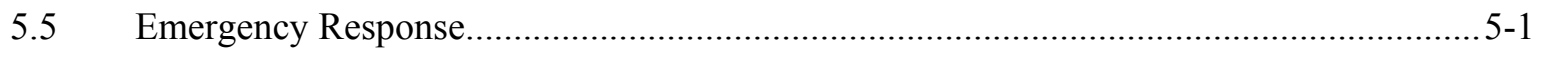

5.6 Tracking, Reporting, and Recordkeeping........................................................................ $5-2$ 
5.7 Training .......

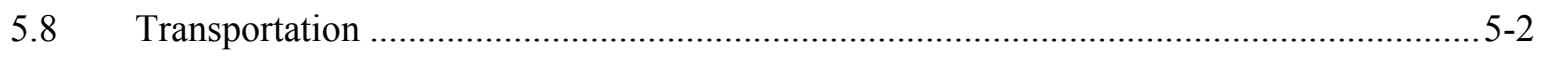

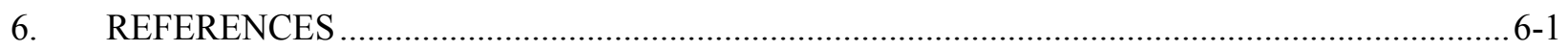

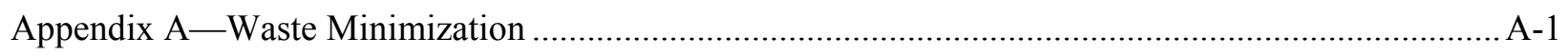

FIGURES

2-1. The INTEC location within Idaho National Laboratory.......................................................2-2

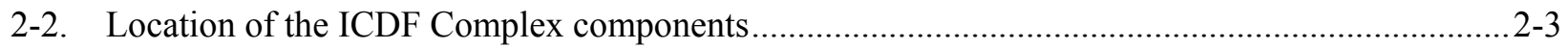

\section{TABLES}

3-1. Waste management during ICDF Complex operations 


\section{ACRONYMS}

AOC area of contamination

CERCLA Comprehensive Environmental Response, Compensation, and Liability Act

CFA Central Facilities Area

CFR Code of Federal Regulations

DOE Department of Energy

DOE-ID Department of Energy Idaho Operations Office

EPA Environmental Protection Agency

HEPA high-efficiency particulate air

HW hazardous waste

ICDF Idaho CERCLA Disposal Facility

INL Idaho National Laboratory

INTEC Idaho Nuclear Technology and Engineering Center

IW industrial waste

LDR land disposal restriction

LLW low-level waste

MLLW mixed low-level waste

O\&M operations and maintenance

OU operable unit

$\mathrm{P} 2 / \mathrm{Wmin} \quad$ pollution prevention and waste minimization

PCB polychlorinated biphenyl

PPE personal protective equipment

RAWP Remedial Action Work Plan

RCRA Resource Conservation and Recovery Act

RCT radiological control technician

ROD Record of Decision 
SSSTF Staging, Storage, Sizing, and Treatment Facility

TSCA Toxic Substances Control Act

USC United States Code

WAC Waste Acceptance Criteria

WAG waste area group

WMP Waste Management Plan 


\section{ICDF Complex Operations Waste Management Plan}

\section{INTRODUCTION}

The U.S. Department of Energy Idaho Operations Office (DOE-ID) authorized a remedial design/remedial action for the Idaho Nuclear Technology and Engineering Center (INTEC) in accordance with the Waste Area Group (WAG) 3, Operable Unit (OU) 3-13 Record of Decision (ROD) (DOE-ID 1999). The OU 3-13 ROD requires the removal and on-Site disposal of some of the Comprehensive Environmental Response, Compensation, and Liability Act (CERCLA) (42 USC § 9601 et seq.) remediation waste generated within the boundaries of the Idaho National Laboratory (INL).

The Idaho CERCLA Disposal Facility (ICDF) Complex is an on-Site, engineered facility, located south of INTEC and adjacent to the old percolation ponds. Designed and authorized to accept not only WAG 3 waste, but also waste from other INL CERCLA actions, the ICDF Complex will include the necessary subsystems and support facilities to provide a complete waste management system.

Only INL on-Site CERCLA waste meeting the Agency-approved Waste Acceptance Criteria (WAC) will be accepted at the ICDF Complex. An important objective of the WAC is to ensure that hazardous and radioactive waste types disposed of in the ICDF landfill or evaporation ponds will not result in exceeding groundwater quality standards in the underlying Snake River Plain Aquifer (SRPA). The WAC includes restrictions on contaminant concentrations (based on groundwater modeling) with the goal of preventing future risk to the SRPA. Waste managed at the ICDF Complex must also meet the National Emission Standards for Hazardous Air Pollutants (NESHAPs) and Clean Air Act (42 USC § 7401 et seq.) applicable or relevant and appropriate requirements and corresponding operational limitations.

The ICDF landfill has a capacity of approximately $510,000 \mathrm{yd}^{3}$. Most of this waste will be contaminated soil, but debris and CERCLA investigation-derived waste also are included in the waste inventory.

\subsection{Purpose and Objectives}

This Waste Management Plan (WMP) is intended to provide a management and planning tool for identifying and managing waste streams generated from ICDF Complex operations.

\subsection{Scope}

This WMP addresses management of waste generated as a result of ICDF Complex operations. Waste management issues arising from on-Site CERCLA remediation activities not associated with the ICDF Complex operations are not discussed in this WMP. 
1-2 


\section{FACILITY DESCRIPTION}

The INTEC location at the INL is shown in Figure 2-1. The ICDF Complex is located south of the INTEC, and ICDF Complex components are shown in Figure 2-2. This figure provides a schematic of the ICDF Complex, which includes the following major components:

- $\quad$ The disposal cells (landfill)

- An evaporation pond, consisting of two cells

- $\quad$ The Staging, Storage, Sizing, and Treatment Facility (SSSTF), which is composed of the decontamination/treatment building, the administrative office trailer (AOT), and several staging and storage areas in the vicinity.

The ICDF Complex, including a buffer zone, covers approximately 40 acres, with a landfill disposal capacity of approximately $510,000 \mathrm{yd}^{3}$. The ICDF landfill meets the substantive requirements of Resource Conservation and Recovery Act (RCRA) Subtitle C (42 USC § 6921 et seq.), Idaho Hazardous Waste Management Act (HWMA 1983), DOE O 435.1, and Toxic Substances Control Act (TSCA) polychlorinated biphenyl (PCB) landfill design and construction requirements (15 USC § 2601 et seq.). The landfill is the consolidation point for CERCLA-generated solid waste within the INL boundaries and, additionally, will receive CERCLA-generated waste outside WAG 3 that meets the land disposal restriction (LDR) requirements, as specified in the ICDF Complex Waste Acceptance Criteria (DOE/ID-10881 [DOE-ID 2006a]).

The evaporation pond, designated as a RCRA Corrective Action Management Unit (CAMU) in the OU 3-13 ROD, will be the treatment site for ICDF landfill leachate and other aqueous waste types generated as a result of operating the ICDF Complex. In addition, other aqueous waste, such as existing OU 3-13 Group 4 and Group 5 purge water, may be treated in the evaporation pond in accordance with the ICDF Complex WAC (DOE-ID 2006a).

Aqueous waste types that cannot be directly treated in the evaporation pond (e.g., petroleum-contaminated liquids) may be stored at the ICDF Complex.

The ICDF Complex will accept CERCLA waste such as low-level waste (LLW), mixed low-level waste (MLLW), hazardous waste (HW), and TSCA remediation waste for disposal. 


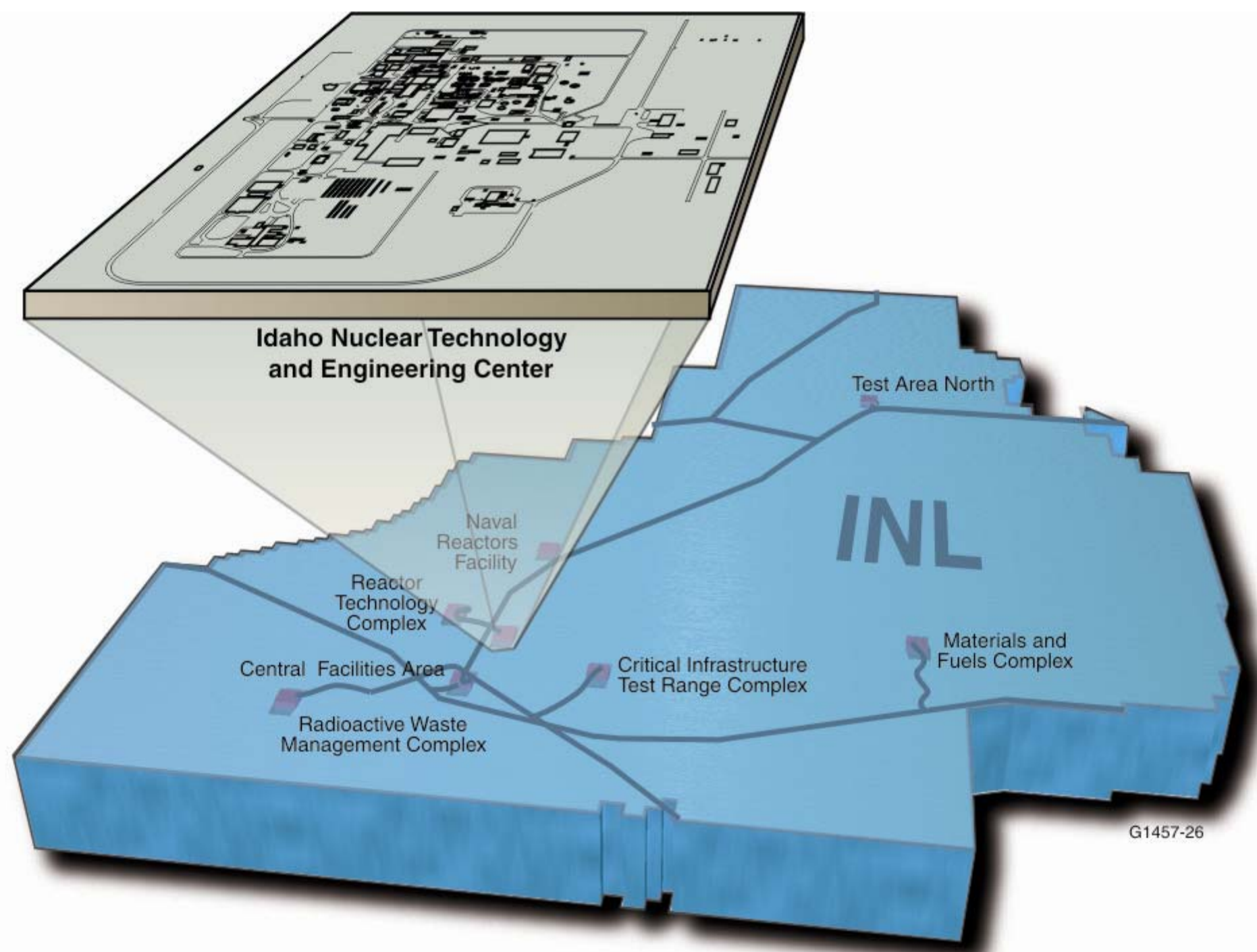

Figure 2-1. The INTEC location within Idaho National Laboratory. 


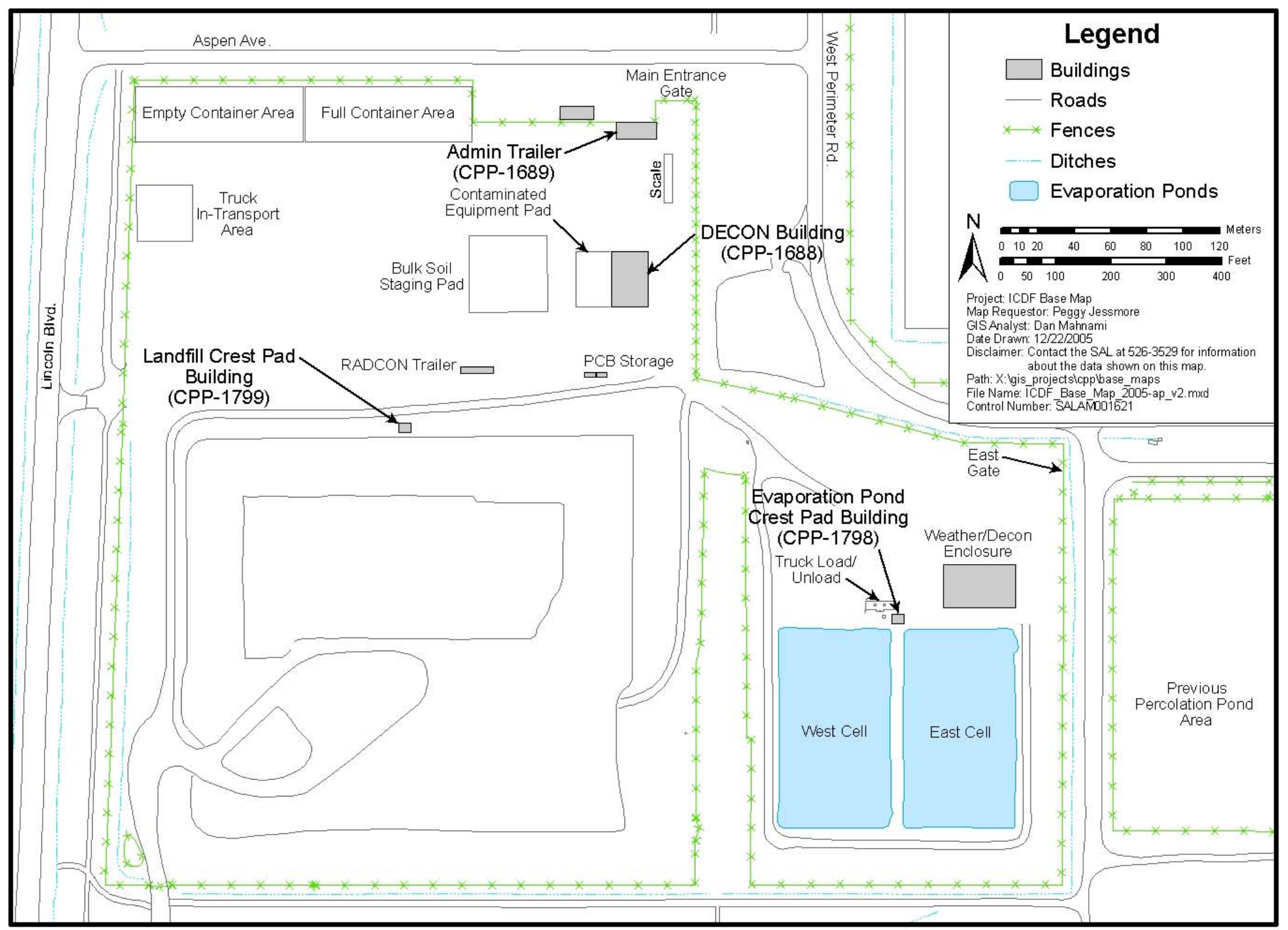

Figure 2-2. Location of the ICDF Complex components. 


\section{WASTE GENERATION}

The following sections provide descriptions of the waste streams expected to be generated as a result of ICDF Complex operations. The ICDF Complex Remedial Action Work Plan (RAWP) and the ICDF Complex Operations and Maintenance Plan (i.e., O\&M Plan) provide further details regarding the ICDF Complex system design and operations (DOE-ID 2006b, 2006c).

All ICDF Complex-generated waste will be managed similar to the management of waste from other ICDF Complex users. Waste types will be identified, containerized, characterized, tracked, staged or stored (if necessary), treated (if necessary), and disposed of as described in the various elements of the ICDF Complex RAWP (DOE-ID 2006b).

\subsection{Waste Management Assumptions}

Waste streams generated by ICDF Complex operations will be managed under the following assumptions:

- All waste generated during the course of ICDF Complex operations is CERCLA remediation waste.

- Waste generated during ICDF Complex operations may be disposed of in the ICDF landfill, subject to meeting the ICDF Complex WAC (DOE-ID 2006a).

- Waste resulting from ICDF Complex operations is generated within the OU 3-13 area of contamination (AOC). Therefore, staging of these waste types in the Bulk Soil Stockpile Staging Area or Full Container Staging Area (40 CFR 264.554) will not trigger placement (DOE-ID 1999). Placement is defined in OSWER Directive 9347.3-05FS (EPA 1989). If waste requires treatment by stabilization in the decontamination/treatment building, this waste will meet LDRs.

- $\quad$ Management of waste generated during ICDF Complex operations will be coordinated with other ICDF Complex operations as described in the ICDF Complex RAWP and ICDF Complex O\&M Plan (DOE-ID 2006b, 2006c).

- $\quad$ ICDF Complex operational waste (e.g., oil/water separator, concrete P-trap, and evaporation pond cleanout) may be disposed to the ICDF landfill provided these waste types meet the ICDF Complex WAC (DOE-ID 2006a). Sediment from the evaporation ponds disposed to the landfill will be treated as necessary, and it will meet the requirements of 40 CFR 268.48.

- Soil waste (soil is defined as materials that are primarily of geologic origin such as sand, silt, loam, or clay, that are indigenous to the natural geologic environment at or near the ICDF Complex, for example, drill cuttings) generated as part of ICDF Complex operations that have triggered placement may be evaluated using the "Alternative LDR Treatment Standards for Contaminated Soil" (40 CFR 268.49). Compliance with 40 CFR 268.49 alternative treatment standards for soil will be accomplished by achieving a $90 \%$ reduction in reasonably expected hazardous waste constituents and by ensuring the soil does not exhibit a characteristic. For soils that carry a U134 hazardous waste code, the soil must undergo testing using Environmental Protection Agency (EPA) SW-846 Test Method $9045 \mathrm{C}$ and documenting that the soil $\mathrm{pH}$ is between 2.0 and 12.5, in addition to the $90 \%$ reduction criteria. Any alternative methods to the above will require Agency concurrence. If any constituent subject to treatment to a $90 \%$ reduction standard will result in a concentration less than 10 times the Universal Treatment Standard for that constituent, treatment to achieve constituent standards less than 10 times the Universal Treatment Standards is not required. 


\subsection{Waste Identification}

Table 3-1 identifies and describes the waste types that are expected to be generated as a result of ICDF Complex operations, management strategies, and the proposed disposition of the waste types. In addition to the waste types included in Table 3-1, alpha low-level waste potentially could be generated by the ICDF Complex due to spill cleanup of temporarily stored waste at the Complex. 
Table 3-1. Waste management during ICDF Complex operations.

\section{Waste Type}

Industrial waste (IW)
Description

Solid waste generated by industrial processes, manufacturing, and support processes (40 CFR 243) that are not defined as hazardous waste or LLW.

Certain waste types, such as

nontraining-related personal protective equipment (PPE);

petroleum-contaminated material such as soil, sand, gravel, or other earthen material, engine oil filters, etc., require a waste stream-specific, documented waste determination per the INEEL Waste Acceptance Criteria

(INEEL WAC) (DOE-ID 2005).

Activities that may generate IW include administrative activities, sampling, and cleanup (e.g., from petroleum spills).
Management Strategy

Disposition

All waste must be characterized,

documented, and tracked if necessary as described in Section 5 of this WMP.

If necessary, solid waste streams (i.e., those with no free liquids) will be staged in the ICDF Complex and managed in accordance with Section 5 of this WMP and Section 5 of the ICDF Complex O\&M Plan (DOE-ID 2006c).

Other liquid waste from ICDF Complex operations will be transferred to the evaporation pond if this waste meets the ICDF Complex WAC (DOE-ID 2006a).

IW will be transported for disposal at the Central Facilities Area (CFA)

Landfill. Recyclable and reusable items are managed under Section 4.2 of this

WMP and Section 4.11 of the ICDF

Complex O\&M Plan, and are not considered waste.

Requirements for disposal (described in the INEEL WAC [DOE-ID 2005) must be met.
INL Landfill Complex or

recycled/reused under the INEEL WAC and this WMP. If waste does not meet the INEEL WAC, waste will be managed at the ICDF Complex or sent to an off-Site facility in accordance with CERCLA off-Site policy (40 CFR 300.440). 
Table 3-1. (continued).

\begin{tabular}{|c|c|c|c|}
\hline Waste Type & Description & Management Strategy & Disposition \\
\hline Low-level waste (LLW) & $\begin{array}{l}\text { Waste that is not high-level radioactive } \\
\text { waste, spent nuclear fuel, transuranic } \\
\text { waste, by-product, or naturally } \\
\text { occurring radioactive material. } \\
\text { Secondary LLW may include soil, solid } \\
\text { sampling and monitoring materials, } \\
\text { tarps, and other material from storage } \\
\text { and staging activities, equipment that } \\
\text { cannot be decontaminated, and other } \\
\text { radiologically contaminated materials } \\
\text { such as petroleum-contaminated media } \\
\text { (i.e., soil or other absorbent materials } \\
\text { containing radiological- and } \\
\text { petroleum-contaminated materials). } \\
\text { Activities that may generate LLW } \\
\text { include sampling and monitoring, } \\
\text { management of storage and staging } \\
\text { areas, decontamination, dust control, } \\
\text { drilling (including drill cuttings), } \\
\text { operation of the oil/water separator, and } \\
\text { stabilization activities. }\end{array}$ & $\begin{array}{l}\text { All waste must be characterized, } \\
\text { documented, and tracked if necessary as } \\
\text { described in Section } 5 \text { of this WMP. } \\
\text { If necessary, solid waste streams } \\
\text { (i.e., those with no free liquids) will be } \\
\text { staged in the ICDF Complex and } \\
\text { managed in accordance with Section } 5 \\
\text { of this WMP and Section } 5 \text { of the ICDF } \\
\text { Complex O\&M Plan (DOE-ID 2006c). } \\
\text { Other liquid waste from ICDF Complex } \\
\text { operations will be transferred to the } \\
\text { evaporation pond if this waste meets the } \\
\text { ICDF Complex WAC (DOE-ID } 2006 a \text { ). } \\
\text { Aqueous waste that does not meet } \\
\text { specific evaporation pond criteria in the } \\
\text { ICDF Complex WAC } \\
\text { (e.g., petroleum-contaminated media } \\
\text { from the oil/water separator) may be } \\
\text { treated to meet the ICDF landfill WAC } \\
\text { and disposed of in the landfill, or held } \\
\text { until appropriate on-Site or off-Site } \\
\text { treatment, storage, or disposal is } \\
\text { arranged. } \\
\text { Secondary LLW generated as a result of } \\
\text { ICDF Complex operations will be } \\
\text { disposed of in the landfill or the } \\
\text { evaporation pond. }\end{array}$ & $\begin{array}{l}\text { ICDF landfill or evaporation pond. } \\
\text { In the unlikely event that liquid or } \\
\text { nonliquid waste does not meet the ICDF } \\
\text { Complex WAC, that waste will be } \\
\text { containerized, treated, and/or stored at } \\
\text { the ICDF Complex as necessary or } \\
\text { required until appropriate on-Site or } \\
\text { off-Site disposal is arranged. }\end{array}$ \\
\hline
\end{tabular}


Table 3-1. (continued).

\begin{tabular}{|c|c|c|c|}
\hline Waste Type & Description & Management Strategy & Disposition \\
\hline Hazardous waste (HW) & $\begin{array}{l}\text { Waste designated as CERCLA, to } \\
\text { include hazardous by the EPA } \\
\text { regulations ( } 40 \text { CFR 261.3). } \\
\text { Secondary HW streams may include } \\
\text { (but are not limited to) soil, materials } \\
\text { that are determined hazardous based on } \\
\text { process knowledge, materials from } \\
\text { sampling activities, unused product that } \\
\text { cannot be recycled, decontamination } \\
\text { materials, and materials used during } \\
\text { sampling or cleanup activities. } \\
\text { Activities that may generate HW } \\
\text { include sampling, management of } \\
\text { storage and staging areas, } \\
\text { decontamination, dust control, drilling } \\
\text { (including purge water and drill } \\
\text { cuttings), use of product that cannot be } \\
\text { recycled, and stabilization activities. }\end{array}$ & $\begin{array}{l}\text { All waste must be characterized, } \\
\text { documented, and tracked as described in } \\
\text { Sections } 4 \text { and } 5 \text { of this WMP. } \\
\text { If necessary, solid waste streams } \\
\text { (i.e., those with no free liquids) will be } \\
\text { staged in the ICDF Complex and } \\
\text { managed in accordance with Sections } 4 \\
\text { and } 5 \text { of this WMP and Section } 5 \text { of the } \\
\text { ICDF Complex O\&M Plan } \\
\text { (DOE-ID 2006c). } \\
\text { Other liquid waste from ICDF Complex } \\
\text { operations will be transferred to the } \\
\text { evaporation pond if this waste meets the } \\
\text { ICDF Complex WAC (DOE-ID } 2006 a \text { ). } \\
\text { Aqueous waste that does not meet the } \\
\text { specific evaporation pond WAC } \\
\text { (e.g., petroleum-contaminated media } \\
\text { from the oil/water separator) may be } \\
\text { treated to meet the ICDF landfill WAC } \\
\text { and disposed of in the landfill, or held } \\
\text { until appropriate on-Site or off-Site } \\
\text { treatment, storage, or disposal is } \\
\text { arranged. }\end{array}$ & $\begin{array}{l}\text { ICDF landfill or evaporation pond. } \\
\text { In the unlikely event that liquid or } \\
\text { nonliquid waste does not meet the ICDF } \\
\text { landfill or evaporation pond WAC, the } \\
\text { waste will be containerized, treated, } \\
\text { and/or stored at the ICDF Complex as } \\
\text { necessary or required until appropriate } \\
\text { on-Site or off-Site treatment, storage, or } \\
\text { disposal is arranged. }\end{array}$ \\
\hline
\end{tabular}


Table 3-1. (continued).

\begin{tabular}{|c|c|c|c|}
\hline Waste Type & Description & Management Strategy & Disposition \\
\hline $\begin{array}{l}\text { Mixed low-level waste } \\
\text { (MLLW) }\end{array}$ & $\begin{array}{l}\text { Waste containing both radioactive and } \\
\text { RCRA-hazardous components. } \\
\text { Secondary MLLW streams may include } \\
\text { (but are not limited to) soil, materials } \\
\text { from sampling activities, } \\
\text { decontamination materials, filters and } \\
\text { other materials associated with dust } \\
\text { control, materials from drilling, } \\
\text { decontamination materials, operating } \\
\text { materials that have become } \\
\text { contaminated, petroleum-contaminated } \\
\text { materials from the oil/water separator, } \\
\text { landfill leachate, and evaporation pond } \\
\text { sediments. } \\
\text { Activities that may generate MLLW } \\
\text { include sampling, management of } \\
\text { storage and staging areas, } \\
\text { decontamination, dust control, drilling } \\
\text { (including purge water and drill } \\
\text { cuttings), stabilization activities, } \\
\text { operation of the oil/water separator, and } \\
\text { landfill and evaporation pond } \\
\text { management activities. }\end{array}$ & $\begin{array}{l}\text { All waste must be characterized, } \\
\text { documented, and tracked if necessary as } \\
\text { described in Section } 5 \text { of this WMP. } \\
\text { If necessary, solid waste streams } \\
\text { (i.e., those with no free liquids) will be } \\
\text { staged in the ICDF Complex and } \\
\text { managed in accordance with Section } 5 \\
\text { of this WMP and Section } 5 \text { of the ICDF } \\
\text { Complex O\&M Plan. } \\
\text { Landfill leachate and liquid from the } \\
\text { decontamination sump are pumped } \\
\text { directly into the evaporation pond. } \\
\text { These waste types will be monitored in } \\
\text { accordance with Section } 4 \text { of the ICDF } \\
\text { Complex O\&M Plan and the ICDF } \\
\text { Complex Operational and Monitoring } \\
\text { Sampling and Analysis Plan } \\
\text { (DOE-ID 2003). } \\
\text { Other liquid waste from ICDF Complex } \\
\text { operations will be transferred to the } \\
\text { evaporation pond if this waste meets the } \\
\text { ICDF Complex WAC (DOE-ID } 2006 a \text { ). } \\
\text { Aqueous waste that does not meet } \\
\text { specific evaporation pond WAC } \\
\text { (e.g., petroleum-contaminated media } \\
\text { from the oil/water separator) may be } \\
\text { treated to meet the ICDF landfill WAC } \\
\text { and disposed of in the landfill, or held } \\
\text { until appropriate on-Site or off-Site } \\
\text { treatment, storage, or disposal is } \\
\text { arranged. }\end{array}$ & $\begin{array}{l}\text { ICDF landfill or evaporation pond. } \\
\text { In the unlikely event that liquid or } \\
\text { nonliquid waste does not meet the ICDF } \\
\text { landfill or evaporation pond WAC } \\
\text { (DOE-ID 2006a), the waste will be } \\
\text { containerized, treated, and/or stored at } \\
\text { the ICDF Complex as necessary or } \\
\text { required until appropriate on-Site or } \\
\text { off-Site treatment, storage, or disposal is } \\
\text { arranged. }\end{array}$ \\
\hline
\end{tabular}


Table 3-1. (continued).

\begin{tabular}{|c|c|c|c|}
\hline Waste Type & Description & Management Strategy & Disposition \\
\hline \multirow{4}{*}{$\begin{array}{l}\text { Asbestos and } \\
\text { polychlorinated biphenyl } \\
\text { (PCB) ( } \leq 500 \mathrm{ppm}) \text { waste } \\
\text { (including radioactively } \\
\text { contaminated asbestos and } \\
\text { PCB waste) }\end{array}$} & $\begin{array}{l}\text { Waste managed strictly under TSCA } \\
\text { regulations. }\end{array}$ & \multirow{4}{*}{$\begin{array}{l}\text { All waste must be characterized, } \\
\text { documented, and tracked as described in } \\
\text { Section } 5 \text { of this WMP. } \\
\text { If necessary, solid waste streams } \\
\text { (i.e., those with no free liquids) will be } \\
\text { staged in the ICDF Complex and } \\
\text { managed in accordance with Section } 5 \\
\text { of this WMP and Section } 5 \text { of the ICDF } \\
\text { Complex O\&M Plan (DOE-ID 2006c). }\end{array}$} & \multirow{4}{*}{$\begin{array}{l}\text { ICDF landfill or evaporation pond. } \\
\text { In the unlikely event that a liquid or } \\
\text { nonliquid waste stream does not meet } \\
\text { the ICDF Complex WAC, the waste will } \\
\text { be containerized, treated, and/or stored } \\
\text { at the ICDF Complex as necessary or } \\
\text { required until appropriate on-Site or } \\
\text { off-Site treatment, storage, or disposal is } \\
\text { arranged. Management of stored waste } \\
\text { will be in accordance with Section } 5 \text { of } \\
\text { the ICDF Complex O\&M Plan } \\
\text { (DOE-ID 2006c). }\end{array}$} \\
\hline & Secondary TSCA-regulated streams & & \\
\hline & $\begin{array}{l}\text { may include (but are not limited to) soil, } \\
\text { materials from sampling and } \\
\text { decontamination activities, and } \\
\text { operating materials that have become } \\
\text { contaminated. }\end{array}$ & & \\
\hline & $\begin{array}{l}\text { Activities that may generate } \\
\text { TSCA-regulated waste include sampling } \\
\text { and decontamination. }\end{array}$ & & \\
\hline
\end{tabular}




\section{GENERAL REQUIREMENTS}

The following sections provide general requirements for managing waste generated during ICDF Complex operations. Waste resulting from the ICDF Complex operations will be managed in accordance with the final ROD for OU 3-13, this WMP, the facility WAC, and related policies and procedures.

\subsection{Characterization}

Generally, waste streams generated as a result of ICDF Complex operations will be characterized as industrial waste (IW). Table 3-1 describes the anticipated waste types, activities that may generate waste streams based on the waste type, management strategies for each waste type, and disposition of the waste streams.

Once the waste stream is characterized, it is identified with a tracking number as described in Section 4.1 of the ICDF Complex O\&M Plan (DOE-ID 2006c), with the exception that IW will not be tracked. Section 5 of this WMP describes the management of waste once it is identified.

\subsection{Use of Process Knowledge}

Waste generated as a result of ICDF Complex operations will be characterized in accordance with the applicable regulations (40 CFR 261.24). Process knowledge may be used to meet all or part of the waste analysis requirements. Typically, process knowledge is used when detailed information on the waste is obtained from existing published or documented studies or when the process is well known. An example of this is the identification of discarded lead shielding with a D008 waste code due to the lead content and previous analysis of similar shielding at the INL.

Process knowledge allows a generator to declare the waste hazardous in lieu of testing. When acceptable process knowledge is documented and auditable to ensure that a particular constituent is not present in the waste, it is not necessary to test for that constituent. For example, if a waste comes from a well-defined process and there are no organic chemicals associated with the process, then it is not necessary to test for volatile and semivolatile organics. When an operations waste is declared hazardous based on process knowledge, the designation and supporting data must be documented using the recordkeeping procedure outlined in Section 10 of the ICDF Complex O\&M Plan.

\subsection{Waste Minimization and Pollution Prevention}

In an effort to minimize waste at the ICDF Complex, all ICDF Complex personnel will complete INL Pollution Prevention Awareness Training. In addition, pollution prevention opportunity assessments for ICDF Complex waste-generating processes will be performed and documented, and environmental support personnel will review work and material purchase orders to ensure that environmentally preferable materials are used effectively. This includes ensuring waste is minimized.

The ICDF Complex will typically produce waste contained in the following categories: IW, LLW, HW, and MLLW. Appendix A includes a waste reduction strategy and disposition pathway for each waste identified. The following sections describe methods for waste minimization and pollution prevention, and they provide examples of the types of waste that are expected to be generated that may be subject to Waste minimization (Wmin)/pollution prevention (P2) practices. 


\subsubsection{Waste Minimization}

The ICDF Complex operations will institute waste minimization procedures to ensure that unnecessary waste will not be generated, as discussed in the INL Site Pollution Prevention Plan (DOE/ID-10333 [DOE-ID 2006d]). The ICDF Complex operations have been designed to minimize waste, and management practices employed throughout the operations of the Complex will ensure minimal waste generation. As the majority of the waste to be generated from ICDF Complex operations will be disposed of in the ICDF landfill, general Wmin techniques will be implemented throughout the operations of the ICDF Complex to reduce the volume of waste ultimately sent to the ICDF landfill. The following practices will support Wmin:

- Where sufficient process knowledge is available to make a hazardous waste determination, use of such data will be considered preferable to collection of additional analytical data; waste characterization will be conducted in accordance with Appendix B of the RAWP (DOE-ID 2006b).

- $\quad$ Excess soil meeting the WAG 3 remedial action objectives for radionuclides will be retained and stockpiled at the ICDF Complex for use in ICDF Complex operations. If the soils are used in the landfill, the radionuclide mass will be tracked so that the total radionuclide mass inventory in the landfill is not exceeded.

- $\quad$ Personnel must reduce HW by segregating hazardous and nonhazardous materials. Hazardous materials are CERCLA waste containing hazardous substances as defined by 40 CFR 261.3.

- $\quad$ Reusable items, such as PPE and tools, will be segregated.

- $\quad$ Contaminated and uncontaminated waste will be segregated.

- $\quad$ Incompatible waste types will be managed and stored separately.

- $\quad$ Personnel should make every attempt to minimize waste through judicious use of consumable materials.

- $\quad$ Every attempt should be made to reduce waste at the source.

- $\quad$ Less hazardous materials should be substituted for more hazardous materials.

- $\quad$ Operations management must focus on avoiding HW when possible.

- Administrative changes, such as inventory control and paper reduction practices, will be implemented.

- $\quad$ Operations at the ICDF landfill will include careful use of dust suppression materials to avoid waste and possible spills.

\subsubsection{Pollution Prevention}

The P2 practices at the ICDF Complex work with Wmin goals to reduce waste generated from project operations. Pollution prevention includes training and incentives to reduce waste at the ICDF Complex. Administrative procedures and project design support the P2 strategy for the ICDF Complex. The INL Site Pollution Prevention Plan (DOE-ID 2006d) outlines project management procedures to implement P2 at projects. Prejob briefings may include a discussion of Wmin/P2 philosophies, depending upon the nature of the work, and management will encourage personnel to continuously attempt to improve methods for minimizing waste. 
Pollution prevention practices will include the following:

- $\quad$ Purchased materials at the ICDF Complex made of recycled material. Administrative materials, trash collection bags, and other items used in the ICDF Complex operations may be purchased that contain recycled material.

- $\quad$ Material substitution. Personnel may replace, reduce, or eliminate materials in processes that generate waste. Solvents may be reduced or eliminated if personnel use a nonhazardous substitute. Oil-based paint may be replaced with a latex variety. Hazardous coatings should be replaced with nonhazardous materials, when available.

- $\quad$ Reuse and recycling. Personnel will explore opportunities to reuse materials whenever feasible. Several waste streams generated during ICDF Complex operations can be reduced or eliminated by reuse or recycling. For example, waste oil and excess fuel can be recycled.

- $\quad$ Reduced waste at its source. Operations waste, particularly waste generated from administrative activities, should be reduced or eliminated by using electronic databases where possible. The O\&M Plan describes the approach for the ICDF Complex to utilize electronic means whenever possible.

- $\quad$ Awareness activities. Prejob briefings can effectively disseminate information about Wmin/P2 to encourage employee contribution to waste minimization practices.

\subsubsection{Office Waste}

Office waste that may be generated at the ICDF Complex includes used toner cartridges and waste paper. Appendix A of this WMP provides additional information regarding the waste reduction strategy and disposition pathway for office waste.

\subsubsection{Low-Level Waste}

Types of LLW that may be generated at the ICDF Complex include, but are not limited to, the following:

- $\quad$ Radiological control technician (RCT) surveillance material

- Anti-contamination clothing

- $\quad$ High-efficiency particulate air (HEPA) filters

- $\quad$ Blotter paper

- $\quad$ Plastic sheeting

- $\quad$ Tape, tools, absorbent, rags

- $\quad$ Personal protective equipment (e.g., respirator cartridges, gloves, boots, and coveralls)

- $\quad$ Defective pumps or other equipment

- $\quad$ Damaged roll-on/roll-off containers.

Appendix A of this WMP provides additional information regarding the waste reduction strategy and disposition pathway for LLW. 


\subsubsection{Hazardous Waste}

Types of HW that may be generated at the ICDF Complex include, but are not limited to, the following:

- $\quad$ Excess chemicals

- $\quad$ Solvent-contaminated rags

- $\quad$ Nickel-cadmium batteries

- $\quad$ Lead acid batteries (if collected for recycling, these are exempt from management as a HW)

- Alkaline batteries that contain mercury, when discarded

- Decontamination liquids/solids

- $\quad$ Off-specification products.

Appendix A of this WMP provides additional information regarding waste reduction strategy and disposition pathway for HW.

\subsubsection{Industrial Waste}

Types of IW that may be generated at ICDF include, but are not limited to, the following:

- Used oil

- $\quad$ Ethylene glycol

- Used tires

- $\quad$ Used wood.

Appendix A of this WMP provides additional information regarding the waste reduction strategy and disposition pathway for IW. 


\section{MANAGEMENT AND DISPOSITION OF WASTE}

Waste generated as a result of ICDF Complex operations is managed as described in Table 3-1. Once characterized, the waste also will be managed under the ICDF Complex O\&M Plan (DOE-ID 2006c).

\subsection{Management in Storage/Staging Areas}

Waste from the ICDF Complex operations may be managed in storage or staging areas, if necessary. These storage and staging areas are described in detail in Section 5 of the O\&M Plan. The ICDF Complex operations waste is generated in the WAG 3 AOC and may be temporarily managed under the substantive requirements of 40 CFR 264.554, "Staging Piles." By managing the waste in the $\mathrm{AOC}$ in this manner, placement will not be triggered. If staging of these various waste types is not appropriate, waste generated as part of ICDF Complex operations may be stored in one of the ICDF Complex storage areas that meet the substantive requirements of 40 CFR 262.34(a)(1). The approach for management in these storage and staging areas is briefly described below.

\subsubsection{Management in Storage Areas}

Liquid waste that cannot be directly disposed of in the ICDF evaporation pond may be stored in one of the ICDF Complex storage areas designated for aqueous storage. Any liquid petroleum-contaminated waste will also be stored in a designated ICDF Complex storage area awaiting treatment or shipment for off-Site disposal.

\subsubsection{Management in Staging Areas}

Solid, nonflowing waste may be staged in one of the designated ICDF Complex staging areas and managed in accordance with Section 5 of the O\&M Plan.

\subsection{Packaging}

Any waste generated as a result of ICDF Complex operations must be properly packaged prior to disposal. Section 4 of the ICDF Complex O\&M Plan explains the requirements for packaging waste for management within the ICDF Complex.

\subsection{Labeling and Marking}

Containers of ICDF Complex operations waste will be labeled and marked according to Section 4 of the O\&M Plan.

\subsection{Waste Inspection}

Waste will be inspected in accordance with Section 8 of the O\&M Plan.

\subsection{Emergency Response}

Emergency response is governed by Section 4 of the O\&M Plan. 


\subsection{Tracking, Reporting, and Recordkeeping}

To ensure that all ICDF Complex operations waste is accurately tracked, all containers of waste will be managed according to Section 4 of the O\&M Plan.

All reports and recordkeeping will comply with the requirements of Section 10 of the O\&M Plan.

\subsection{Training}

During waste management operations, any training will be provided in accordance with Section 2 of the O\&M Plan.

\subsection{Transportation}

Transportation of ICDF Complex operations waste, if necessary, will be performed under Section 4 of the O\&M Plan. 


\section{REFERENCES}

40 CFR 243, 1999, "Guidelines for the Storage and Collection of Residential, Commercial, and Institutional Solid Waste," Code of Federal Regulations, Office of the Federal Register, July 1999.

40 CFR 261, 1999, "Identification and Listing of Hazardous Waste," Code of Federal Regulations, Office of the Federal Register, July 1999.

40 CFR 261.3, 1999, "Definition of Hazardous Waste," Code of Federal Regulations, Office of the Federal Register, July 1999.

40 CFR 261.24, 1999, "Toxicity Characteristic," Code of Federal Regulations, Office of the Federal Register, July 1999.

40 CFR 262, 1999, "Standards Applicable to Generators of Hazardous Wastes," Code of Federal Regulations, Office of the Federal Register, July 1999.

40 CFR 262.34, 1999, “Accumulation Time," Code of Federal Regulations, Office of the Federal Register, July 1999.

40 CFR 264, 1999, "Standards for Owners and Operators of Hazardous Waste Treatment, Storage, and Disposal Facilities," Code of Federal Regulations, Office of the Federal Register, July 1999.

40 CFR 264.554, 1999, "Staging Piles," Code of Federal Regulations, Office of the Federal Register, July 1999.

40 CFR 268, 1999, "Land Disposal Restrictions," Code of Federal Regulations, Office of the Federal Register, July 1999.

40 CFR 268.48, 1999, "Universal Treatment Standards," Code of Federal Regulations, Office of the Federal Register, July 1999.

40 CFR 268.49, 1999, “Alternative LDR Treatment Standards for Contaminated Soil," Code of Federal Regulations, Office of the Federal Register, July 1999.

40 CFR 300, 1994, "National Oil and Hazardous Substance Pollution Contingency Plan," Code of Federal Regulations, Office of the Federal Register, September 1994.

40 CFR 300.440, 1999, "Procedures for Planning and Implementing Off-Site Response Actions," Code of Federal Regulations, Office of the Federal Register, July 1999.

67 FR 2962, “Amendments to the Corrective Action Management Unit Rule; Final Rule," Federal Register, U.S. Environmental Protection Agency, January 2002.

15 USC $\S 2601$ et seq., 1976, “Toxic Substance Control Act (TSCA) of 1976," United States Code.

42 USC $\S 6921$ et seq., 1976, Subtitle C, "Hazardous Waste Management," in "Resource Conservation and Recovery Act of 1976," United States Code (as amended).

42 USC § 7401 et seq., 1970, "Clean Air Act,” United States Code, December 31, 1970. 
42 USC $\S 9601$ et seq., 1980, “Comprehensive Environmental Response, Compensation and Liability Act of 1980 (CERCLA/Superfund)," United States Code, December 11, 1980.

DOE-ID, 1999, Final Record of Decision, Idaho Nuclear Technology and Engineering Center, Operable Unit 3-13, DOE/ID-10660, Rev. 0, Department of Energy Idaho Operations Office, U.S. Environmental Protection Agency Region 10, and State of Idaho Department of Health and Welfare, October 1999.

DOE-ID, 2003, ICDF Complex Operational and Monitoring Sampling and Analysis Plan, DOE/ID-11005, Rev. 0, Department of Energy Idaho Operations Office, February 2003.

DOE-ID, 2005, Idaho National Engineering and Environmental Laboratory Waste Acceptance Criteria, DOE/ID-10381, Rev. 21, U.S. Department of Energy Idaho Operations Office, January 2005.

DOE-ID, 2006a, ICDF Complex Waste Acceptance Criteria, DOE/ID-10881, Rev. 3, Department of Energy Idaho Operations Office, October 2006.

DOE-ID, 2006b, ICDF Complex Remedial Action Work Plan, DOE/ID-10984, Rev. 1, Department of Energy Idaho Operations Office, December 2006.

DOE-ID, 2006c, ICDF Complex Operations and Maintenance Plan, DOE/ID-11000, Rev. 2, Department of Energy Idaho Operations Office, February 2006.

DOE-ID, 2006d, INL Site Pollution Prevention Plan, DOE/ID-10333, Rev. 1, Department of Energy Idaho Operations Office, July 2006.

DOE O 435.1, 2001, “Radioactive Waste Management,” U.S. Department of Energy, August 28, 2001.

EPA, 1989, Superfund LDR Guide \#5: Determining When Land Disposal Restrictions (LDRs) Are Applicable to CERCLA Response Actions, OSWER Directive 9347.3-05FS, United States Environmental Protection Agency, Office of Solid Waste and Emergency Response, July 1989.

HWMA, 1983, “Hazardous Waste Management Act of 1983," Idaho Code Sections 39-4401 et seq., 1983. 
Appendix A

Waste Minimization 


$$
\text { A-2 }
$$




\section{Appendix A}

\section{Waste Minimization}

\begin{tabular}{|lc|lc|}
\hline Preparer & Tracking No. & \\
& P. J. Jessmore & & 4.12 \\
\hline Date & & Revision & 0 \\
& $5 / 01 / 02$ & & 0 \\
\hline
\end{tabular}

\section{A-1. PURPOSE}

The purpose of this overview is to (1) identify waste generated at the ICDF Complex and (2) identify a waste reduction strategy.

\section{A-2. SCOPE AND APPLICABILITY}

This overview applies to waste generated at the ICDF Complex including office waste, LLW, HW, and IW. It includes a waste reduction strategy and a disposition pathway for each waste identified.

\section{A-3. REGULATORY REQUIREMENTS}

None identified.

\section{A-4. EQUIPMENT}

None identified.

\section{A-5. IMPLEMENTATION}

Implementation may include the following activities:

- All ICDF Complex employees - complete Pollution Prevention Awareness Training as described in the ICDF Complex Health and Safety Plan.

- ICDF Complex Environmental Support personnel—review work and material purchase orders to ensure environmentally preferable materials are used effectively. This includes ensuring waste is minimized.

- $\quad$ Schedule, perform, and document the results of Pollution Prevention Opportunity Assessments for ICDF Complex waste-generating processes.

- $\quad$ Document quantities of waste generated, recycled, excessed, sent off-Site, or to the CFA landfill.

- $\quad$ Prepare the biennial report on EPA Form 8700-13B. Include the following:

- $\quad$ Efforts undertaken during the year to reduce the volume and toxicity of waste generated

- $\quad$ Changes in volume and toxicity of waste actually achieved during the year in comparison to previous years to the extent such information is available. 
The ICDF Complex will typically produce waste contained in the following categories: office waste, LLW, HW, and IW. The following sections are separated into these categories and include a waste reduction strategy and disposition pathway for each waste identified.

\section{A-5.1 Office Waste} following:

Office waste that may be generated at the ICDF Complex includes, but is not limited to, the

- Used toner cartridges

- Waste paper.

The waste reduction strategy and disposition pathway for office waste is provided in Table A-1.

Table A-1. Office waste reduction strategy and disposition pathway.

\begin{tabular}{lll}
\hline \multicolumn{1}{c}{ Waste Stream } & \multicolumn{1}{c}{ Waste Reduction Strategy } & \multicolumn{1}{c}{$\begin{array}{c}\text { Disposition } \\
\text { Pathway }\end{array}$} \\
\hline $\begin{array}{l}\text { Used toner cartridges } \\
\text { Waste paper }\end{array}$ & $\begin{array}{l}\text { The ICDF Complex will replace cartridges only when necessary. } \\
\text { The ICDF Complex plans to do as much as possible } \\
\text { electronically, eliminating excess paper. }\end{array}$ & Recycle \\
\hline
\end{tabular}

\section{A-5.2 Low-level Waste}

Types of LLW that may be generated at the ICDF Complex include, but are not limited to, the following:

- $\quad$ RCT surveillance material

- Anti-contamination clothing

- HEPA filters

- Blotter paper

- $\quad$ Plastic sheeting

- $\quad$ Tape, tools, absorbent, rags

- $\quad$ PPE (e.g., respirator cartridges, gloves, boots, and coveralls).

The waste reduction strategy and disposition pathway for LLW is provided in Table A-2.

Table A-2. Low-level waste reduction strategy and disposition pathway.

\begin{tabular}{|c|c|c|}
\hline Waste Stream & Waste Reduction Strategy & $\begin{array}{l}\text { Disposition } \\
\text { Pathway }\end{array}$ \\
\hline RCT surveillance material & $\begin{array}{l}\text { The ICDF Complex will minimize the amount of material } \\
\text { taken into contamination areas. }\end{array}$ & ICDF landfill ${ }^{\mathrm{a}}$ \\
\hline Anti-contamination clothing & $\begin{array}{l}\text { The ICDF Complex will minimize the amount of material } \\
\text { taken into contamination areas. }\end{array}$ & ICDF landfill $^{\mathrm{a}}$ \\
\hline HEPA filters & The ICDF Complex will only change filters when necessary. & ICDF landfill $^{\mathrm{a}}$ \\
\hline
\end{tabular}


Table A-2. (continued).

\begin{tabular}{llc}
\hline \multicolumn{1}{c}{ Waste Stream } & \multicolumn{1}{c}{ Waste Reduction Strategy } & $\begin{array}{c}\text { Disposition } \\
\text { Pathway }\end{array}$ \\
\hline Blotter paper & $\begin{array}{l}\text { The ICDF Complex will minimize the amount of material } \\
\text { taken into contamination areas. }\end{array}$ & ICDF landfill $^{\text {a }}$ \\
Plastic sheeting & $\begin{array}{l}\text { The ICDF Complex will minimize the amount of material } \\
\text { taken into contamination areas. }\end{array}$ & ICDF landfill $^{\text {a }}$ \\
Tape, tools, absorbent, rags & $\begin{array}{l}\text { The ICDF Complex will minimize the amount of material } \\
\text { taken into contamination areas. }\end{array}$ & ICDF landfill $^{\text {a }}$ \\
PPE & $\begin{array}{l}\text { The ICDF Complex will minimize the amount of material } \\
\text { taken into contamination areas. }\end{array}$ & ICDF landfill $^{\text {a }}$ \\
\hline a. Must meet the ICDF Complex WAC.
\end{tabular}

\section{A-5.3 Hazardous Waste}

Types of HW that may be generated at the ICDF Complex include, but are not limited to, the following:

- $\quad$ Excess chemicals

- $\quad$ Solvent-contaminated rags

- $\quad$ Nickel cadmium batteries

- $\quad$ Lead acid batteries (if collected for recycling, these are exempt from management as a HW)

- Alkaline batteries that contain mercury, when discarded

- Decontamination liquids/solids.

The waste reduction strategy for HW is provided in Table A-3.

Table A-3. Hazardous waste reduction strategy and disposition pathway.

\begin{tabular}{lll}
\hline \multicolumn{1}{c}{ Waste Stream } & \multicolumn{1}{c}{ Waste Reduction Strategy } & \multicolumn{1}{c}{ Disposition Pathway } \\
\hline Excess chemicals & $\begin{array}{l}\text { The ICDF Complex will ensure that all chemicals } \\
\text { and quantities have a specific use. }\end{array}$ & $\begin{array}{l}\text { Place on INL excess chemical } \\
\text { inventory list }\end{array}$ \\
$\begin{array}{l}\text { Solvent-contaminated } \\
\text { rags }\end{array}$ & $\begin{array}{l}\text { The ICDF Complex will minimize the amount of } \\
\text { material used and will look for alternative } \\
\text { nonhazardous products to replace solvents. }\end{array}$ & $\begin{array}{l}\text { Characterize and manage per the } \\
\text { WMP }\end{array}$ \\
$\begin{array}{l}\text { Nickel cadmium } \\
\text { batteries }\end{array}$ & $\begin{array}{l}\text { The ICDF Complex will only change batteries } \\
\text { when necessary. }\end{array}$ & Recycle \\
Lead acid batteries & $\begin{array}{l}\text { The ICDF Complex will only change batteries } \\
\text { when necessary. }\end{array}$ & Recycle \\
Incandescent lamps & $\begin{array}{l}\text { Use long-life halide bulbs if possible. The ICDF } \\
\text { Complex will only change bulbs when necessary. }\end{array}$ & Recycle \\
$\begin{array}{l}\text { Decontamination } \\
\text { liquids/solids }\end{array}$ & $\begin{array}{l}\text { Decontamination activities will only be performed } \\
\text { when required. }\end{array}$ & Liquids - ICDF evaporation pond ${ }^{\text {a }}$ \\
\hline \begin{tabular}{l} 
a. Must meet the ICDF Complex WAC. \\
\hline
\end{tabular}
\end{tabular}




\section{A-5.4 Industrial Waste}

Types of IW that may be generated at the ICDF Complex include, but are not limited to, the following:

- Used oil

- $\quad$ Ethylene glycol

- $\quad$ Used tires

- $\quad$ Used wood

The waste reduction strategy for IW is provided in Table A-4.

Table A-4. Industrial waste reduction strategy and disposition pathway.

\begin{tabular}{|c|c|c|}
\hline Waste Stream & Waste Reduction Strategy & Disposition/Treatment \\
\hline Used oil & ICDF will only change oil when necessary. & $\begin{array}{l}\text { Recycle (on-spec) or send } \\
\text { off-Site (off-spec) }\end{array}$ \\
\hline Ethylene glycol & ICDF will only replace ethylene glycol when necessary. & Off-Site \\
\hline Used tires & ICDF will only change tires when necessary. & Excess through excess yard \\
\hline Used wood & Good operating practice. Reuse whenever possible. & $\begin{array}{l}\text { Excess through excess yard or } \\
\text { send to ICDF landfill }{ }^{\mathrm{a}}\end{array}$ \\
\hline
\end{tabular}

\section{A-6. REFERENCES AND INTERFACES}

Training references and interfaces remain to be determined.

\section{A-7. RECORDS}

Records will include the following:

- Operations records containing information on types and quantities of waste generated and disposed of at the ICDF Complex

- $\quad$ Shipping Records (for waste dispositioned at locations other than the ICDF)

- $\quad$ EPA Form 8700-13B

- $\quad$ Pollution Prevention Opportunity Assessment results. 